\title{
Densities and \\ Biomass Relationships of Birds Nesting in Boreal Forest Habitats
}

\author{
L. N. CARBYN ${ }^{1}$
}

\begin{abstract}
A spot mapping technique was applied to obtain quantitative data on bird populations on 25 -acre ( 10 hectare) plots in northern boreal forest habitats. The number of breeding passerines varied from 15 to 42 pairs per plot. The number of species varied from 6 to 11 breeding passerines and 4 to 8 non-passerines and non-breeding passerines. Biomass of the breeding passerines ranged from 3100 to 5496 grams per 100 acres ( 40 hectare). Members of the Fringillidae family contributed the highest percentage of the total avian biomass, followed by Turdidae, Parulidae, Bombycillidae, Sylviidae, Paridae and Tyrannidae.
\end{abstract}

RÉSUMÉ. Densités et rapports de biomasse chez des oiseaux nichant sur des aires d'étude. Dans des habitats de forêt boréale nordique, on a appliqué, sur des aires de 25 acres (10 hectares), une technique de cartographie ponctuelle pour obtenir des données quantitatives sur les populations d'oiseaux. De 15 à 42 paires de passereaux couvaient sur chaque aire. Le nombre d'espèces variait de 6 à 11 pour les passereaux couvant et de 4 à 8 pour les passereaux qui ne couvaient pas et pour les non passereaux. D'une aire à l'autre, la biomasse des passereaux couvant variait de 3100 à 5496 grammes par 100 acres (40 hectares). Le plus grand pourcentage de la biomasse aviaire totale était formé par les membres de la famille des Fingillidés, suivis par les Turdidés, les Parulidés, les Bombycillidés, les Sylviidés, les Paridés et les Tyrannidés.

РЕЗЮМЕ. Исследование плотности популячий и биомассы птии, әнездлиихся в зоне лесов дореального Типа. Были проведены исследования для получения количественных данных по популяциям птиц, гнездящихся на экспериментальных участках площадью 10 га в зоне северных лесов бореального типа. Численность гнездящихся воробьиных на отдельных ушяетпех -изменялась в пределах от 15 до 42 пар, в то время как численность различпых видов колебалась от 6 до 11 среди гнездящихся воробьиных и от 4 до 8 среди представителей других отрядов и негнездящихея воробьиных. Биомасса гнездящихся воробьиных изменялась в пределах от 3100 до 5496 г/100 акров (40 га). Наибольшее процентное содержание биомассы приходилось на долю семейства Fringillidae. Остальную часть биомассы составляли представители семейств Turdidae, Parulidae, Bombycillidae, Sylviidae, Paridae и Tyrannidae.

\section{INTRODUCTION}

The avifauna of the Canadian subarctic regions has not been intensively studied in the past. In 1964 a biological station was established at Heart Lake, Northwest Territories (Fig. 1), under the auspices of the University of Alberta, to provide facilities for the study of biota of the North American taiga (northern boreal forests) essentially unaltered by man. Highway construction, mineral and oil ex-

\footnotetext{
${ }^{1}$ Canadian Wildlife Service, Edmonton, Alberta, Canada.
} 


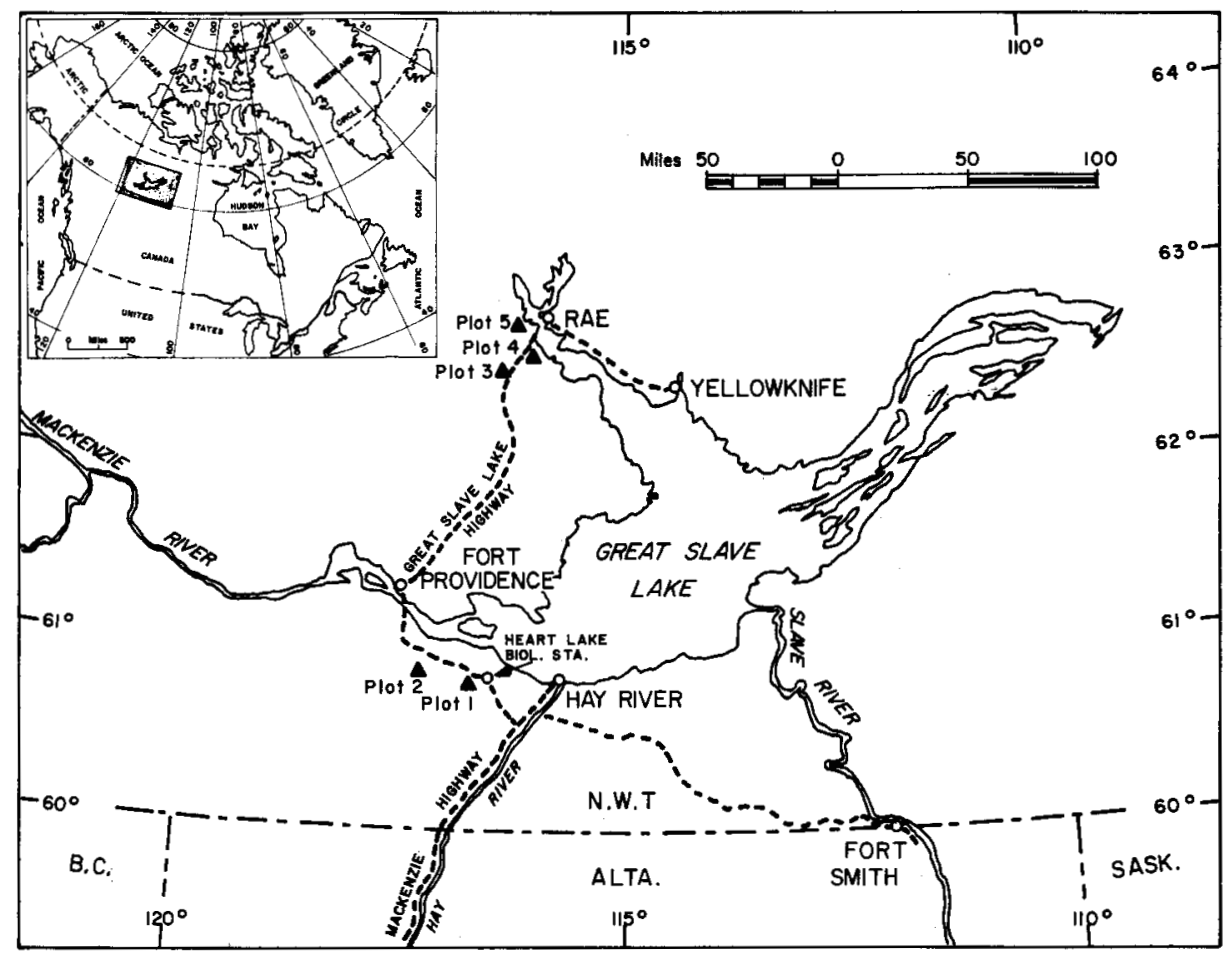

FIG. 1. Map of the area around Great Slave Lake, Northwest Territories, Canada. The locations of the 5 study plots are indicated.

ploration, promotion of the tourist trade, commercial fishing, and lumbering have begun to change the landscape southwest, and northwest of Great Slake Lake.

This paper describes densities, biomass relationships, and methods of enumerating migratory passerine birds found nesting in that area on 5 plots selected in undisturbed northern boreal forest habitats. A list of non-passerines and nonbreeding passerines present on the plots is also included. Detailed studies of bird species to habitat associations were not carried out. Collection of such data would have to be preceded by plant community studies in which the characteristics of the vertical components (strata) of the habitat would be evaluated quantitatively and qualitatively.

\section{STUDY AREA}

Field work was carried out along the Mackenzie-Great Slave Lake highways from May to July in 1965 and 1966 (Fig. 1). The area lies within the boreal forest biome as described by Shelford (1963). Two life zones, the Canadian and Hudsonian, are recognized within this biome. Plots 1 and 2 are all located within the general region defined as the Canadian life zone and plots 3,4 and 5 are within the transition area between the Canadian and the Hudsonian zones. 
With increased latitude the more shaded, moss-coniferous forests characteristic of the Canadian life zone merge into open lichen-scrub forests characteristic of the Hudsonian life zone. The change between the life zones is not abrupt and no sharp phytogeographical dividing lines separate them. Local edaphic conditions greatly influence the vegetational cover, which has been described by Rowe (1959).

\section{BRIEF DESCRIPTION OF VEGETATION ON THE PLOTS}

Five 25 -acre (10 hectare) plots were selected. Initially an attempt was made to select areas with a uniform dominant vegetational cover. Because of the size of the plots this was difficult to achieve.

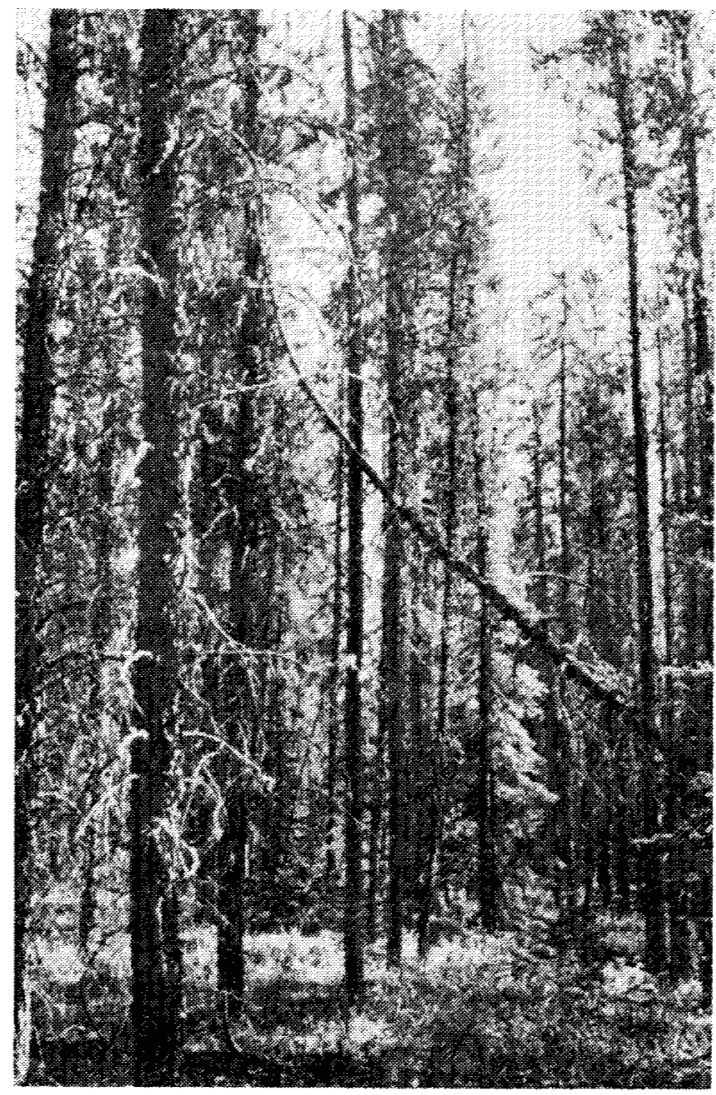

FIG. 2. Open jackpine stand (Plot 1).

\section{Plot 1.}

Jackpine (Pinus banksiana) (Fig. 2) and trembling aspen (Populus tremuloides) form a semi-open stand in the central area of the plot. This grades into a small stand of pure aspen (Fig. 3). The shrub stratum in the plot is sparse, consisting mainly of Juniperus communis, Juniperus horizontalis, Potentilla fruticosa, Shepherdia canadensis, Viburnum edule, and Rosa sp. Arctostaphylos uva-ursi is an important ground cover plant. 


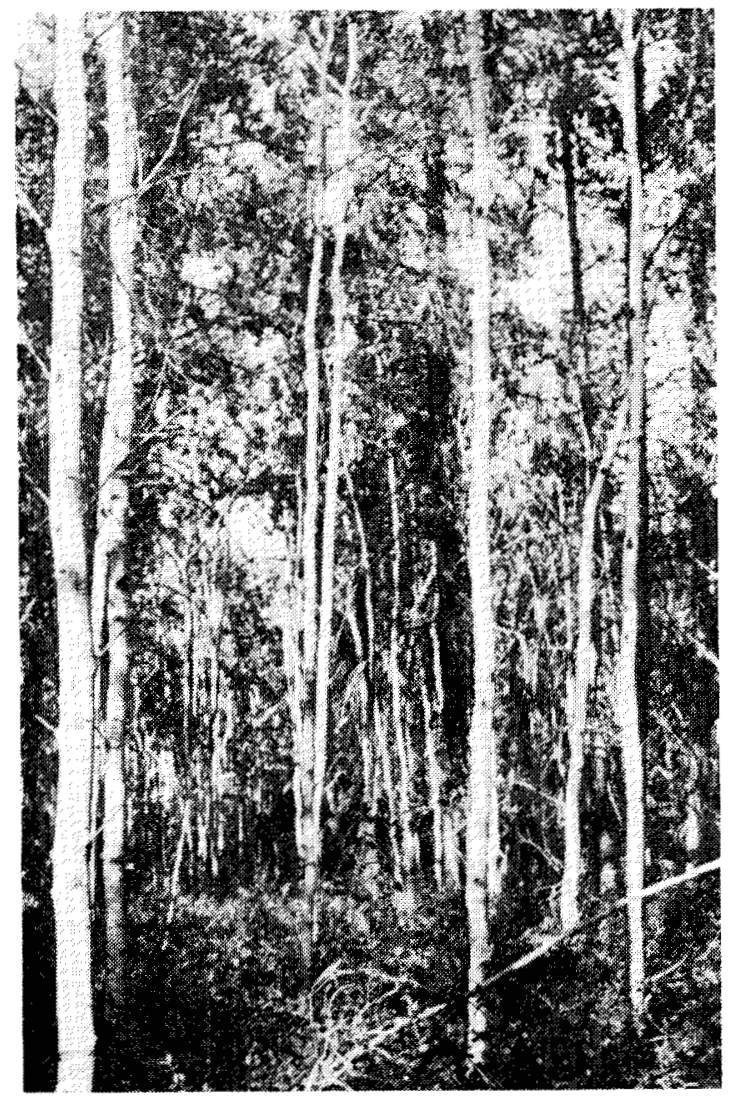

FIG. 3. Aspen stand on plot 1 that integrates with jackpine stand.

Plot 2.

Plot 2 has the greatest diversity of plant communities. Black spruce (Picea mariana) trees form scattered thickets within a feather moss - black spruce association (Fig. 4) as described by Moss (1955). Empetrum nigrum and Vaccinium vitis-idaea together with various mosses are the major components of the ground cover. The shrub stratum is composed of larch (Larix laricina), black spruce, Salix sp., Vaccinium myrtilloides, Ribes sp., Shepherdia canadensis and Potentilla fruticosa.

Scattered tall larch trees fringe a central sedge marsh area. Two small stands of tall black spruce and white spruce (picea glauca) trees are located on higher, well drained ground.

Plot 3.

Vegetation on Plot 3 is characteristic of the vegetational communities found in much of the Hudsonian life zone. Black spruce dominate the area (Fig. 5). Charred logs are evidence of fire. Lichens form the main ground cover, but the depressions support various mosses. Shepherdia canadensis, Potentilla fruticosa, Betula glandulosa, and Ledum groenlandicum are dominant in the shrub cover. 


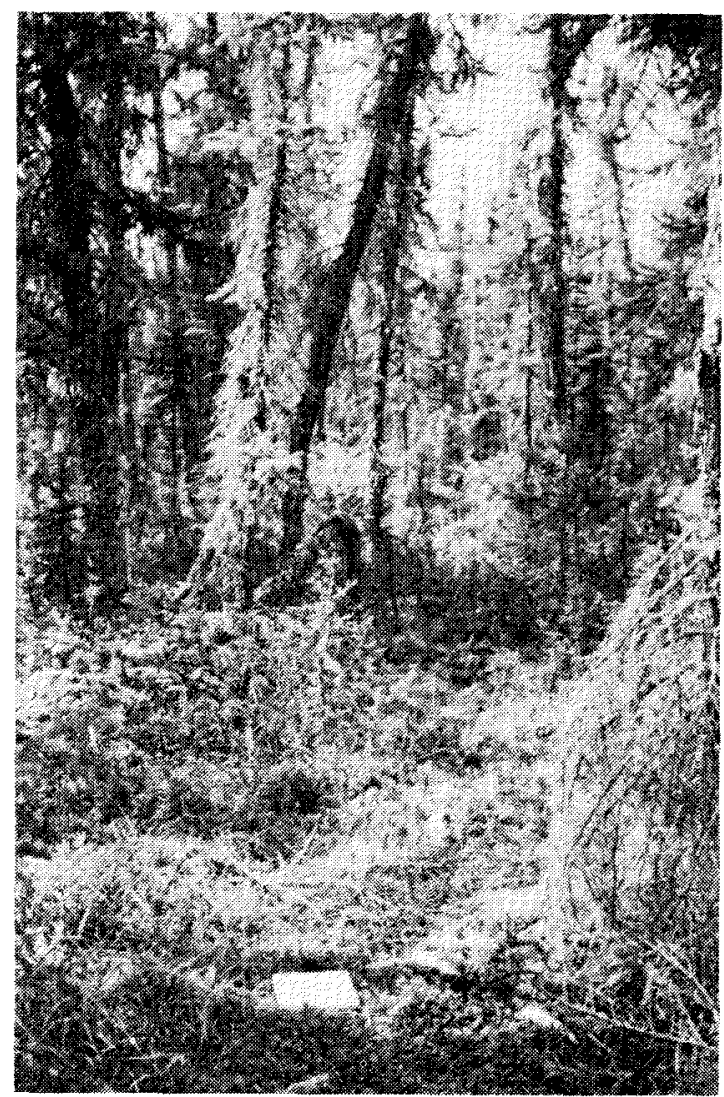

FIG. 4. Black spruce trees forming the dominant tree cover in a feather moss-black spruce association (Plot 4).

Plot 4.

Species composition of the dominant plants is similar to that of Plot 2. The tree cover and shrub stratum vary considerably in density.

\section{Plot 5 .}

The major portion of this plot consists of an open black spruce-sphagnum bog. The most striking structural feature of the ground cover is the presence of sphagnum mounds. The shrub stratum is dominated by Ledum groenlandicum, Chamaedaphne calyculata, Andromeda polifolia, Larix laricina, and Betula glandulosa.

\section{METHODS}

A census of the breeding passerine bird populations was conducted by the Williams spot-mapping technique (Hall 1964). This method is designed to record the number of territorial males present on plots.

Each 25 -acre plot was divided into 8 columns by 7 parallel lines, and 8 rows by 7 other parallel lines at right angles to the first set. The lines closest to the boundaries were 75 feet from them, and the remaining 5 lines were spaced 150 


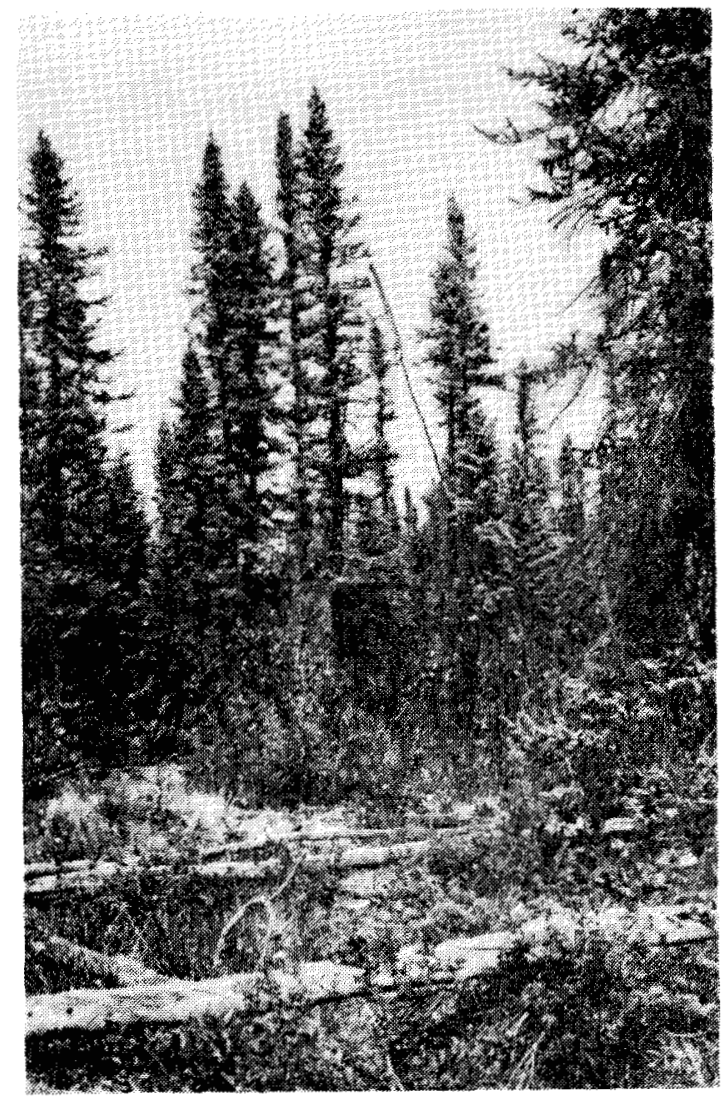

FIG. 5. Open canopied subarctic forest characteristic of the Hudsonian life zone.

feet apart. Thus each plot was divided into 28 smaller sections around the edge of the plot and 36 larger squares within the plot. The intersections of this grid system were marked with red surveyor's tape and the nearest trees numbered.

I counted birds while walking along one set of parallel lines at an average speed of 50 feet per minute. The average sampling time spent per plot per morning was approximately 140 minutes. Locations of all birds heard singing or seen were plotted on maps. Symbols were used to indicate such activities as singing, nestbuilding, fighting, feeding, and flying and the flight direction. Sex and age of birds seen were recorded whenever possible.

All males singing simultaneously were recorded, and I often spent additional time locating them.

At the end of each count the data were transposed to summary sheets. After completing all the counts on a plot, the locations of the singing males were plotted on composite maps, using the clusters of points so obtained, and the evidence of males heard simultaneously; lines delineating territories were drawn around each singing male. If the territory of a male was only partly within a plot then only half a territory was listed for that male. In all the calculations of the populations on the plots it was assumed that each singing male represented a pair of breeding birds. 
TABLE 1. Number of territorial passerine males recorded per 25 -acre (10 hectare) plot, and number of individuals and biomass in grams of passerine birds as calculated on the basis of 100 acres (40 hectare). Species are listed in order of A.O.U. checklist, 1957.

\begin{tabular}{|c|c|c|c|c|c|c|c|c|c|c|c|c|c|c|c|}
\hline \multirow{3}{*}{ Species } & \multicolumn{3}{|c|}{ Plot 1} & \multicolumn{3}{|c|}{ Plot 2} & \multicolumn{3}{|c|}{ Plot 3} & \multicolumn{3}{|c|}{ Plot 4} & \multicolumn{3}{|c|}{ Plot 5} \\
\hline & \multirow{2}{*}{$\begin{array}{c}\text { Males } \\
\text { per } \\
25 \text { acres }\end{array}$} & \multicolumn{2}{|c|}{ Per 100 acres } & \multirow{2}{*}{$\begin{array}{c}\text { Males } \\
\text { per } \\
25 \text { acres }\end{array}$} & \multicolumn{2}{|c|}{ Per 100 acres } & \multirow{2}{*}{$\begin{array}{c}\text { Males } \\
\text { per } \\
25 \text { acres }\end{array}$} & \multicolumn{2}{|c|}{ Per 100 acres } & \multirow{2}{*}{$\begin{array}{c}\text { Males } \\
\text { per } \\
25 \text { acres }\end{array}$} & \multicolumn{2}{|c|}{ Per 100 acres } & \multirow{2}{*}{$\begin{array}{c}\text { Males } \\
\text { per } \\
25 \text { acres }\end{array}$} & \multicolumn{2}{|c|}{ Per 100 acres } \\
\hline & & No. & Biomass & & No. & Biomass & & No. & Biomass & & No. & Biomass & & No. & Biomass \\
\hline $\begin{array}{l}\text { Paridae } \\
\quad \text { Parus hudsonicus }\end{array}$ & - & - & - & 1 & 8 & 88 & - & - & - & 1 & 8 & 88 & - & - & - \\
\hline $\begin{array}{l}\text { Turdidae } \\
\text { Turdus migratorius } \\
\text { Hylocichla guttata } \\
\text { Hylocichla ustulata } \\
\text { Hylocichla minima }\end{array}$ & $\frac{2}{2.5^{*}}$ & $\frac{16}{20}$ & $\frac{1408}{620}$ & $\frac{1}{4}$ & $\frac{8}{32}$ & $\frac{704}{992}$ & $\begin{array}{l}1 \\
1 \\
1 \\
2\end{array}$ & $\begin{array}{r}8 \\
8 \\
8 \\
16\end{array}$ & $\begin{array}{l}704 \\
240 \\
248 \\
464\end{array}$ & $\frac{1}{2}$ & $\frac{8}{16}$ & $\frac{704}{496}$ & $\begin{array}{l}- \\
1 \\
-\end{array}$ & $\begin{array}{r}-8 \\
8 \\
-\end{array}$ & $\begin{array}{l}\overline{240} \\
248 \\
-\end{array}$ \\
\hline $\begin{array}{l}\text { Sylviidae } \\
\quad \text { Regulus calendula }\end{array}$ & $0.5^{*}$ & 4 & 24 & 6 & 48 & 288 & - & - & - & 1 & 8 & 48 & - & - & - \\
\hline $\begin{array}{l}\text { Bombycillidae } \\
\text { Bombycilla garrula }\end{array}$ & 2 & 16 & 928 & - & - & - & 1 & 8 & 464 & - & - & - & - & - & - \\
\hline $\begin{array}{l}\text { Parulidae } \\
\text { Vermivora peregrina } \\
\text { Dendroica coronata } \\
\text { Dendroica striata } \\
\text { Dendroica palmarum }\end{array}$ & $\begin{array}{l}3 \\
8 \\
- \\
\end{array}$ & $\begin{array}{l}24 \\
64 \\
- \\
-\end{array}$ & $\begin{array}{l}216 \\
768 \\
- \\
-\end{array}$ & $\begin{array}{l}\frac{4}{5} \\
0.5^{*}\end{array}$ & $\frac{32}{40}$ & $\begin{array}{r}288 \\
480 \\
\frac{-}{40}\end{array}$ & $\begin{array}{l}-5^{*} \\
1.5^{*}\end{array}$ & $\begin{array}{l}\overline{12} \\
12 \\
16\end{array}$ & $\begin{array}{l}\overline{144} \\
144 \\
160\end{array}$ & $\begin{array}{l}\overline{2.5^{*}} \\
\overline{-}\end{array}$ & $\begin{array}{l}\overline{20} \\
-\end{array}$ & $\begin{array}{l}\overline{240} \\
- \\
-\end{array}$ & $\frac{\overline{2}}{5.5^{*}}$ & $\frac{\overrightarrow{16}}{44}$ & $\begin{array}{l}\overline{192} \\
\overline{440}\end{array}$ \\
\hline Total & $29.5^{*}$ & 236 & 5292 & 42 & 336 & 5496 & $15.5^{*}$ & 124 & 3252 & $18.5^{*}$ & 148 & $31 C 0$ & $25.5^{*}$ & 204 & 3380 \\
\hline
\end{tabular}

*Includes birds whose territories were only partially within the plot. 
The number of males recorded for each species on a 25 -acre plot was multiplied by 8 to estimate the number of individuals of each species per 100 acres (40 hectares). Biomass values were obtained for each species by multiplying the number of individuals of each species by the average weight of each species. The average weights were determined from specimens in the University of Alberta Museum of Zoology; whenever possible averages were based on 10 adults, 5 males and 5 females.

Counting was carried out in the early morning on generally clear and calm days. Counts were conducted on at least 3 consecutive days because territories were expected to change due to predation and other factors during the breeding season (Enemar 1959). Therefore widely spaced counts would probably not have yielded the exact number of territories on the plots within a given period of time. At least 7 early morning counts were taken on each plot from 28 May to 30 June in either 1965 or 1966.

\section{RESULTS}

Members of the finch (Fringillidae) and new world warbler (Parulidae) families were generally the most common breeding birds on the plots (Table 1). Species of the titmouse (Paridae), new world flycatcher (Tyrannidae), and waxwing (Bombycillidae) families were represented only by scattered breeding pairs. Members of the thrush family (Turdidae) were present on all plots.

The species of non-passerine and non-breeding passerine birds recorded on the plots are listed in Table 2. These species did not seem to utilize exclusively

TABLE 2. Number of times that non-passerines and non-breeding passerines were recorded on each study plot.

\begin{tabular}{|c|c|c|c|c|c|}
\hline Species & Plot $1(9)^{*}$ & Plot 2(7)* & Plot 3(7)* & Plot 4(7)* & Plot 5(8)* \\
\hline $\begin{array}{l}\text { Anatidae } \\
\text { Anas platyrhynchos }\end{array}$ & 0 & 0 & 0 & 0 & 0 \\
\hline Accipitridae & & & & & \\
\hline $\begin{array}{l}\text { Accipiter striatus } \\
\text { Circus cyaneus }\end{array}$ & 1 & $\begin{array}{l}0 \\
0\end{array}$ & $\begin{array}{l}0 \\
0\end{array}$ & $\begin{array}{l}1 \\
0\end{array}$ & 1 \\
\hline Falconidae & & & & & \\
\hline $\begin{array}{l}\text { Falco sparverius } \\
\text { Tetraonidae }\end{array}$ & 0 & $\mathbf{0}$ & 1 & 0 & 0 \\
\hline $\begin{array}{l}\text { Tetraonidae } \\
\text { Canachites canadensis }\end{array}$ & 2 & 3 & 1 & 1 & 0 \\
\hline $\begin{array}{l}\text { Scolopacidae } \\
\text { Capella gallinago } \\
\text { Totanus flavipes }\end{array}$ & $\begin{array}{l}0 \\
0\end{array}$ & $\begin{array}{l}3 \\
0\end{array}$ & $\begin{array}{l}1 \\
0\end{array}$ & $\begin{array}{l}1 \\
0\end{array}$ & $\begin{array}{l}0 \\
3\end{array}$ \\
\hline $\begin{array}{l}\text { Strigidae } \\
\text { Bubo virginianus }\end{array}$ & 1 & 0 & $\mathbf{0}$ & 0 & 0 \\
\hline $\begin{array}{l}\text { Picidae } \\
\text { Colaptes auratus } \\
\text { Picoides tridactylus }\end{array}$ & $\begin{array}{l}3 \\
0\end{array}$ & $\begin{array}{l}1 \\
1\end{array}$ & $\begin{array}{l}0 \\
0\end{array}$ & $\begin{array}{l}4 \\
1\end{array}$ & $\begin{array}{l}0 \\
0\end{array}$ \\
\hline $\begin{array}{l}\text { Hirundinidae } \\
\text { Iridoprogne bicolor }\end{array}$ & $\mathbf{0}$ & $\mathbf{0}$ & $\mathbf{0}$ & 1 & $\mathbf{0}$ \\
\hline $\begin{array}{l}\text { Corvidae } \\
\text { Perisoreus canadensis }\end{array}$ & 9 & 7 & 1 & 7 & 5 \\
\hline $\begin{array}{l}\text { Fringillidae } \\
\text { Pinicola enucleator } \\
\text { Loxia leucoptera }\end{array}$ & $\begin{array}{l}0 \\
0\end{array}$ & $\begin{array}{l}1 \\
0\end{array}$ & $\begin{array}{l}\mathbf{0} \\
\mathbf{0}\end{array}$ & $\begin{array}{l}\mathbf{0} \\
\mathbf{0}\end{array}$ & $\begin{array}{l}\mathbf{0} \\
2\end{array}$ \\
\hline
\end{tabular}

*The figures in parentheses refer to the maximum number of encounters possible, i.e. total number of visits to the plot by the observer. 
TABLE 3. Biomass of birds in grams per 100 acres (40 hectares) calculated for each family of passerines nesting on the study plots. Percentages of biomass for each family per plot are listed.

\begin{tabular}{lrrrrrrrrrrrr}
\hline & \multicolumn{2}{c}{ Plot 1 } & \multicolumn{2}{c}{ Plot 2 } & \multicolumn{3}{c}{ Plot 3 } & \multicolumn{2}{c}{ Plot 4 } & \multicolumn{2}{c}{ Plot 5 } \\
Family & \multicolumn{1}{c}{ Biomass } & $\%$ & Biomass & $\%$ & \multicolumn{1}{c}{ Biomass } & $\%$ & Biomass & $\%$ & Biomass & $\%$ \\
\hline $\begin{array}{l}\text { Fringillidae } \\
\text { (Graminivorous) }\end{array}$ & 1328 & 25.1 & 2472 & 45.0 & 684 & 21.2 & 1524 & 49.2 & 2260 & 66.9 \\
$\begin{array}{l}\text { Turdidae } \\
\text { (Omnivorous) }\end{array}$ & 2028 & 38.3 & 1696 & 31.0 & 1656 & 50.9 & 1200 & 38.7 & 488 & 14.4 \\
$\begin{array}{l}\text { Parulidae } \\
\text { (Insectivorous) }\end{array}$ & 984 & 18.5 & 808 & 15.0 & 448 & 13.7 & 240 & 7.7 & 632 & 18.7 \\
$\begin{array}{l}\text { Sylviidae } \\
\text { (Insectivorous) }\end{array}$ & 24 & .5 & 288 & 5.0 & - & - & 48 & 1.5 & - & - \\
$\begin{array}{l}\text { Paridae } \\
\text { (Insectivorous) }\end{array}$ & - & - & 88 & 2.0 & - & - & 88 & 2.9 & - & - \\
$\begin{array}{l}\text { Bombycillidae } \\
\text { (Omnivorous) }\end{array}$ & 928 & 17.5 & - & - & 464 & 14.2 & - & - & - & - \\
$\begin{array}{l}\text { Tyrannidae } \\
\text { (Insectivorous) }\end{array}$ & - & - & 88 & 2.0 & - & - & - & - & - & - \\
\hline Total Biomass & 5292 & & 5496 & & 3252 & & 3100 & & 3380 & \\
\hline
\end{tabular}

the area within the plots and no data on the size of territories or home ranges were obtained. Others, such as the very common Gray Jay (Perisoreus canadensis) and White-winged crossbill (Loxia leucoptera) had completed nesting activity before this study began. Only one pair of the latter species was still found nesting on Plot 4 at the time of the surveys.

Total biomass of the breeding passerine birds varies considerably for the different plots (Table 1). For each plot the biomass values were calculated for the different families (Table 3 ). The graminivores and the omnivores contributed the highest percentages to the avian biomass for the breeding birds that were included in the census. Also included in this table are the percentages that the biomass of each family contributes to total biomass of breeding passerine birds. The family Fringillidae contributed most to the total avian biomass on plots 2,4 and 5 . On plots 1 and 3 the biomass of the thrushes was greatest. Small populations of thrushes, because of their larger individual size, added significantly to the avian biomass. Warblers, though common, usually added less to the total biomass.

\section{DISCUSSION}

Many factors control the accuracy of a census that is based on the number of singing males. Important factors are the variation in seasonal and daily intensities of singing activity.

In the present study the maximum early morning singing activity for finches (Fringillidae) and warblers (Parulidae) was from 0100 to 0430 hrs. After 0430 hrs. the intensity of singing by all species, including primarily evening songsters such as the thrushes (Turdidae), dropped significantly. Enemar (1959) found that in southern Sweden (approximate latitude $56^{\circ} \mathrm{N}$.) singing activity in passerines during the breeding season continued throughout the day. However, the intensity of song decreased from early morning to afternoon. In Abisko, Swedish Lapland (latitude $68^{\circ} \mathrm{N}$.) Armstrong (1954) found that the period of maximum singing 
activity for most passerines was between midnight and $0430 \mathrm{hrs}$. Similar results are recorded by Weeden (1965) for Tree Sparrows (Spizella arborea) in Alaska (latitude $65^{\circ} \mathrm{N}$.). Seasonal changes in the singing activity of birds are also directly related to the stages in the breeding cycle (Nice 1937; Enemar 1959; Weeden 1965). Singing activity is generally greatest at the onset of territorial activity, and ceases altogether during the postnuptial moult. Because of the short summer, the breeding season of the migratory birds in northern latitudes is telescoped and breeding periods of the various species are synchronous. In the boreal forest, the onset of nesting activity of passerines is probably directly related to environmental conditions in spring. Thus the optimum time to conduct the counts can be expected to vary slightly from year to year depending on whether spring is late or early. In this study the stages of the breeding cycle of passerines were determined from data on nests found. It was found that the optimum periods of the census during the summers of 1965 and 1966 were from 5 to 27 June.

Other factors that affect precision are weather conditions and walking speed along census lines. Rain, high winds and extremes in temperature lower the intensity and duration of singing (Armstrong 1954). In this study counts were carried out only when the weather was calm and clear or partially overcast. A slow walking speed partially compensates for a decrease in intensity of bird song under adverse weather conditions. However, I maintained a fairly constant rate of 50 feet per minute, regardless of small changes in environmental conditions.

One source of error inherent in the Williams' spot-mapping method is the assumption that one singing male represents one breeding pair of birds. It is known that some unmated males may also defend territories. For example, males without mates amounted to 9 per cent of a House Wren (Troglodytes aedon) population (Kendeigh 1944) and 16 per cent of a Song Sparrow population (Nice 1937). Similarly unmated males were reported for an insular Song Sparrow population by Tompa (1962).

Polygyny has been observed in 14 of 291 species of North American passerines (Verner and Willson 1966). However, most of the polygynous species were breeding in areas of abundant food supply such as marshes. Because of the low densities of birds in this study, it is unlikely that any of the passerines were polygynous. Furthermore, none of the known polygynous species as reported by Verner and Willson was encountered on the plots.

Delineating territories on composite maps is another source of error, because the records of singing locations are often spread evenly over a considerable area. The problem was reduced by marking on the field maps the locations of the males that were singing simultaneously. A certain amount of subjectivity was unavoidable. I believe that in areas of high densities the actual number of territories may be overestimated. For example, slate-colored Juncos (Junco hyemalis) were very common in open spruce bogs and extensive movement of one male could have resulted in the recording of two territories for the one individual.

Competition, predation, and nest destruction may cause mid-season shifting of territories (Hall 1964). Errors due to this factor were minimized because counts on each plot were conducted on at least three consecutive mornings and not spread over the whole season. 
Accuracy of results is related to plot size, especially when counts are reported as number per 100 acres. A minor inaccuracy in the number of males on a small area would be magnified considerably when converted to a total number of birds per 100 acres. Another disadvantage of small plots is that their perimeter-to-area ratio is inversely proportional to plot size. A greater percentage of territories will, therefore, lie partly outside the plot as plot size is reduced. Plots must also be large enough to include the activity of most of the birds breeding in the area. On the other hand, in very large plots (greater than 50 acres, i.e. 20 hectare) the morning activity may decline before the count on the plot can be completed.

The feeding habits of birds were not studied in detail and the general groupings: graminivores, omnivores, and insectivores, were chosen after Turcek (1956) and Salt (1957). Food habits of birds often change seasonally; hence it is quite likely that birds categorized as omnivorous and graminivorous in this study may feed to a large extent on insects during the summer months when this source of food is readily available.

\section{ACKNOWLEDGEMENTS}

I am grateful to Drs. J. J. Hickey and R. W. Nero for their review of the original thesis manuscript. Drs. D. R. Flook, W. A. Fuller and V. Lewin provided helpful suggestions and criticisms on the original manuscript of this paper. The research was supported by a National Research Council of Canada grant to Dr. V. Lewin of the University of Alberta.

\section{REFERENCES}

AMERICAN ORNITHOLOGISTS' UNION. 1957. Check-list of North American birds. 5th ed. Baltimore, Md.: Lord Baltimore Press. 691 pp.

ARMSTRONG, E. A. 1954. The behaviour of birds in continuous daylight. Ibis, 96: 1-30.

ENEMAR, A. 1959. On the determination of the size and composition of a passerine bird population during the breeding season. Var Fagelvarld, Supplement 2. 114 pp.

HALL, G. A. 1964. Breeding bird census - why and how. Audubon Field Notes, 18: 413-16.

KENDEIGH, c. s. 1944. Measurement of bird populations. Ecological Monographs, 14: 67-106.

MOSS, E. H. 1955. The vegetation of Alberta. Botanical Review, 21: 493-567.

NICE, M. M. 1937. Studies in the life history of the Song Sparrow. 1. A Population Study of the Song Sparrow. Transactions of Linnaean Society of New York, 4. 247 pp.

Rowe, J. S. 1959 . Forest regions of Canada. Dept. of Northern Affairs and Natural Resources, Ottawa. Bulletin 123.71 pp.

SALT, G. W. 1957. An analysis of avifaunas in the Teton mountains and Jackson Hole, Wyoming. Condor, 59 (6): 373-93.

SHELFORD, v. E. 1963. The ecology of North America. Urbana: University of Illinois Press. $610 \mathrm{pp}$.

TOMPA, F. S. 1962. Territorial behavior: the main controlling factor of a local Song Sparrow population. $A u k, 79$ (4): 687-97.

TURCEK, F. J. 1956. On the bird population of the spruce forest community in Slovakia. Ibis, 98: 24-33.

VERNER, J. and M. F. WILLSON. 1966. The influence of habitats on mating systems of North American passerine birds. Ecology 47 (1): 143-47.

WEEDEN, S. J. 1965. Territorial behavior of the Tree Sparrow. Condor, 67 (3): 193-209. 